To Maega : Jurnal Pengabdian Masyarakat

Bulan-Tahun, Vol.3, No.2, hal.92-103

$\operatorname{ISSN}(P): 2622-6332 ; \operatorname{ISSN}(E): 2622-6340$

http://www.ojs.unanda.ac.id/index.php/tomaega

\title{
Pelatihan Teknik Budidaya Ubikayu Nuabosi Menggunakan Teknologi Pola Tanam Tumpangsari Dengan Tanaman Legum Di Desa Randotonda Kecamatan Ende Kabupaten Ende
}

\author{
Willybrordus Lanamana ${ }^{1, a, *}$, Kristono Yohanes Fowo ${ }^{2, b}$, Laurentius \\ Dominicus Gadi Djou ${ }^{3, c}$, Yohanes Pande ${ }^{4, d}$ \\ 1,2,3,4 Universitas Flores Ende Nusa Tenggara Timur \\ a,b,c,dEmail:wlanamana@yahoo.com,kristonoyf@gmail.com,gadidjou@yahoo.com, \\ pandejohanes@gmail.com \\ *Correspondent Email: wlanamana@yahoo.com
}

Article History:

Received: 25-06-2020; Received in Revised: 09-07-2020; Accepted: 18-07-2020

DOI: http://dx.doi.org/10.35914/tomaega.v3i2.376

\begin{abstract}
Abstrak
Mitra dalam pelaksanaan kegiatan pengabdian ini adalah kelompok tani Kema Tau Pawe, yang dibentuk tahun 2010. Salah satu komoditas tanaman pangan yang dibudidayakan yaitu ubikayu varietas lokal Nuabosi. Ubikayu ini merupakan komoditas unggulan daerah. Permasalahan utama, teknik budidaya masih dilakukan secara konvensional, petani belum membuat guludan, tanpa pemupukan, jarak tanam yang tidak teratur, dan jarang melakukan pembersihan gulma, sehingga produktivitasnya rendah. Tujuan pelaksanaan pengabdian untuk melakukan perbaikan teknis budidaya menggunakan teknologi pola tanam tumpangsari ubikayu dan tanaman legum. Metode yang digunakan, penyuluhan dan pelatihan. Kegiatan pengabdian ini diawali dengan penyuluhan teknik budidaya. Materi pelatihan meliputi, teknik pembuatan guludan, pemanfaatan sereza dan pengaplikasian promi, pelatihan pola tanam tumpangsari serta pelatihan pembersihan gulma dan pembumbunan. Dari pretest dan posttest yang diberikan terjadi peningkat nilai yang signifikan pada posttest. Pada materi teknik pembuatan guludan rata-rata pretest 5,68, posttest meningkat sebesar 12,6, materi pemanfaatan sereza dan pemberian promi, rata-rata pretest 5,52, posttest meningkat sebesar 13,64, materi pola tanam tumpangsari rata-rata pretest 5,6, posttest meningkat sebesar 13,56 dan untuk materi pembumbunan dan pembersihan gulma, rata-rata pretest 5,52, posttest meningkat sebesar 14,2. Perbaikan teknis budidaya meliputi; pembuatan guludan, pemanfaatan sereza dan pengaplikasian promi, polatanam tumpangsari, pembersihan gulma dan pembumbunan.
\end{abstract}

Kata Kunci: Tumpangsari Legum, Ubikayu Nuabosi

\section{Abstract}

Partner in the implementation of community service activity was Kema Tau Pawe farmer group, which was formed in 2010. One of the food crop commodities cultivated by this farmer group was Nuabosi cassava, in which this cassava was their regional superior commodity. The main problem of Nuabosi cassava cultivation was that the cultivation technique was still performed conventionally, in which farmers did not make mounds, did not perform fertilization, planted the plants in irregular spacing, and rarely performed 
weed control, so that it led to the low productivity. The specific objective of the implementation of this service activity was to carry out technical improvements in Nuabosi cassava cultivation using the Nuabosi cassava intercropping system with legumes. Methods used were counseling and training methods. The community service activity was begun with counseling about cultivation techniques. There were four materials provided in training, such as techniques for making mounds, the use of cereals and application of promi, training in intercropping system and training for weed control and embellishments. Based on pretest and posttest given to famer group for the four materials, it was found that there was significant increase in the posttest score. First, in the material containing techniques for making mounds, the average of pretest score was 5.68, and it increased in the posttest, which was 12.6. Next, in the material about the use of cereals and application of promi, the average of pretest score was 5.52, and it increased in the posttest, which was 13.64. Then, in the material about intercropping system the average of pretest score was 5.6, and it increased in the posttest, which was 13,56. The last, in the material about weed control and embellishments, the average of pretest score was 5.52, and it increased in the posttest, which was 14.2. Technical improvements for cultivation include; making mounds, the use of cereals and application of promi, intercropping, weed control and embellishments.

Keywords: Intercropping Legumes, Nuabosi Cassava

\section{Pendahuluan}

Desa Randotonda merupakan salah satu desa di Kecamatan Ende, Kabupaten Ende Propinsi Nusa Tenggara Timur, terletak di dataran rendah dan lereng bukit, curah hujan $300 \mathrm{~mm}$ pertahun, bulan hujan 5 bulan, suhu rata-rata harian $26^{\circ} \mathrm{c}$, ketinggian tempat 600 meter dpl. Desa ini merupakan desa subur, sehingga sebagian besar masyarakat $95 \%$ perkerjaan utamanya bertani. Usaha tani masyarakat Desa Randotonda selain tanaman pangan; ubikayu, jagung dan hortikultura juga memiliki tanaman perkebunan diantaranya, cengkeh dan kakao serta usaha ternak skala rumah tangga. Pendidikan formal masyarakat Desa Randotonda sebagian besar tidak tamat SLTA, pendidikan non formal berupa penyuluhan dan pelatihan dari berbagai pihak masih sangat terbatas, hal ini terlihat dari pengetahuan dan keterampilan dalam melaksanakan kegiatan usaha tani. Desa Randotonda merupakan desa sentra produksi ubikayu varietas lokal, dengan bahasa setempat disebut ubikayu Nuabosi.

Ubikayu Nuabosi merupakan salah satu komoditas unggulan daerah, komoditas ini memiliki beberapa kelebihan diantaranya; memiliki cita rasa yang enak, gurih, tekstur empuk, dan kadar HCN rendah, umbi rebus yang empuk dan gurih tetap dapat dinikmati setelah umbi dingin, sedangkan pada ubikayu lain menjadi lebih keras (Arsa et al., 2015). Permintaan ubikayu Nuabosi cukup tinggi, baik untuk kebutuhan pasar lokal maupun pasar di luar Kabupaten Ende, siapa saja yang datang berkunjung ke Ende akan membawah oleh-oleh ubikayu lokal tersebut. Perhatian serius terhadap ubikayu ini sejalan dengan kebijakan diversifikasi pangan pemerintah dalam meningkatkan industri pangan berbahan 
baku ubikayu, sehingga ubikayu tersebut layak dijadikan sumber konsumsi karbohidrat alternatif bagi masyarakat.

Permasalahan utama yang ditemukan di lapangan, dimana teknik budidaya ubikayu Nuabosi masih dilakukan secara konvensional, petani belum membuat guludan, tanpa pemupukan, jarak tanam yang tidak teratur, dan jarang melakukan pembersihan gulma, sehingga produktivitasnya masih rendah. Hasil wawancara dengan kepala desa, produktivitas ubikayu Nuabosi baru mencapai 17,50 ton per hektar, jika dibandingkan dengan produktivitas nasional tahun 2018 sudah mencapai 24,4 ton/ha (BPS., 2018). Beberapa fakta di atas memperjelas bahwa petani ubikayu Nuabosi merupakan petani skala kecil, pengetahuan, keterampilan dan modal yang terbatas, luasan lahan sebagian besar dibawah 0,25 hektar, pendapatan rendah, karena harga jualnya relatif murah Rp. 7000/kg ditingkat petani. Realitas ini sejalan dengan pemikiran Chepng'etich, et al., (2015), dimana sistem pertanian skala kecil biasanya ditandai oleh sumber daya yang terbatas, sehingga upaya peningkatkan efisiensi alokasi input dalam suatu sistem usahatani skala kecil dengan keterbatasan sumberdaya adalah kunci menuju peningkatan ketersediaan pangan rumah tangga (Itam et al., 2015).

Upaya untuk mendukung program pemerintah daerah tentang diversifikasi pangan, maka pada tahun 2020 dilaksanakan kegiatan Pengabdian Kepada Masyarakat (PKM) dengan skema Program Pengembangan Desa Mitra (PPDM) didukung pendanaan dari Kemenristek/BRIN, kegiatan yang dilakukan salah satunya adalah pelatihan teknik budidaya ubikayu Nuabosi menggunakan teknologi pola tanam tumpangsari dengan tanaman legum.

Tumpangsari merupakan teknik budidaya tanaman yang lebih dari satu jenis pada sebidang lahan yang sama secara bersamaan di waktu yang sama maupun agak berbeda (Francis et al., 2006; Sullivan, 2000). Tumpangsari merupakan praktek pertanian yang efektif untuk meningkatkan produktivitas tanaman, meningkatkan aktivitas mikroba tanah, dan meningkatkan kandungan nutrisi pada tanah (Li et al., 2011). Manfaat yang terkait dengan tumpangsari meliputi; peningkatan kesuburan tanah (Shen \& Chu., 2004), mengurangi resiko kegagalan panen, jenis komoditi yang dihasilkan beragam, penganekaraman gizi masyarakat, hemat dalam pemakaian sarana produksi, resiko kegagalan panen dapat di perkecil dan meningkatkan biodiversitas (Sembirin et al., 2015) mengurangi penyakit tanaman (Zinsou et al., 2004), dan mengurangi gulma (Amanullah et al., 2007). Dalam praktek tumpangsari tanaman ubikayu dan legum dengan memperhatikan jarak tanam dan waktu tanam dapat meningkatkan produktivitas (Nyi, T.et al., 2014).

Tujuan umum dari pelaksanaan kegiatan ini adalah untuk meningkatkan kemandirian dan kesejahteraan masyarakat desa secara terpadu dan berkelanjutan, sedangkan tujuan khususnya untuk melakukan perbaikan teknis budidaya ubikayu Nuabosi dengan menggunakan teknologi pola tanam tumpangsari ubikayu 
Nuabosi dengan tanaman legum. Melalui kegiatan pengabdian kepada masyarakat ini kelompok tani Kema Tau Pawe diharapkan mampu melakukan teknik budidaya ubikayu Nuabosi dengan teknologi pola tanam tumpangsari dengan tanaman legum, diawali dengan pengolahan lahan secara tepat, pembuatan guludan, pemanfaatan sereza, pengaturan jarak tanam ubikayu dan kacang tanah, pembumbunan dan pembersihan gulma.

\section{Metode}

Waktu pelaksanaan penyuluhan dan pelatihan disepakati selama 5 hari, setiap hari Selasa dan Kamis, dimulai dari tanggal 3 Maret 2020 jam 09.00 - 12.00 WITA, di Desa Randotonda bertempat di kebun ubikayu milik Lorensius Setu, salah satu anggota kelompok tani. Jumlah peserta pelatihan 25 orang. Karakteristik peserta; 15 orang perempuan dan 10 orang laki-laki, pendidikan formal tamat SD 15 orang, tamat SMP 8 orang, dan tamat SMA 2 orang. Untuk mengetahui seberapa jauh pengetahuan dan keterampilan yang dterima peserta pelatihan, dilakukan dengan cara bertanya kesetiap peserta, mengamati kegiatan peserta setelah diberi pelatihan, dan memberi pretest dan posttest, soal yang diberikan dalam bentuk pilihan ganda sebanyak 15 soal. Metode yang digunakan adalah metode penyuluhan dan pelatihan dengan memperbanyak demonstrasi.

\section{Hasil dan Pembahasan}

Pelaksanaan kegiatan penyuluhan dan pelatihan diawali dengan beberapa persiapan yaitu a) persiapan tempat pelaksanaan pelatihan, kegiatan ini berhubungan dengan penentuan lokasi kebun milik anggota kelompok tani yang digunakan untuk pelatihan. b) persiapan peralatan dan bahan, peralatan yang disiapkan meliputi; parang, pacul, penggaruk, skop, hand sprayer dan meteran. Bahan yang disiapkan meliputi, tali, promi, air, stek ubikayu dan benih kacang tanah. Pada tahapan persiapan dilakukan pula pendataan areal lahan dan kesepakatan jadwal penyuluhan dan pelatihan bersama anggota kelompok tani bertempat di kantor desa, kegiatan dimaksud pada Gambar 1 dan Gambar 2, jadwal penyuluhan dan pelatihan pada Tabel 1. 


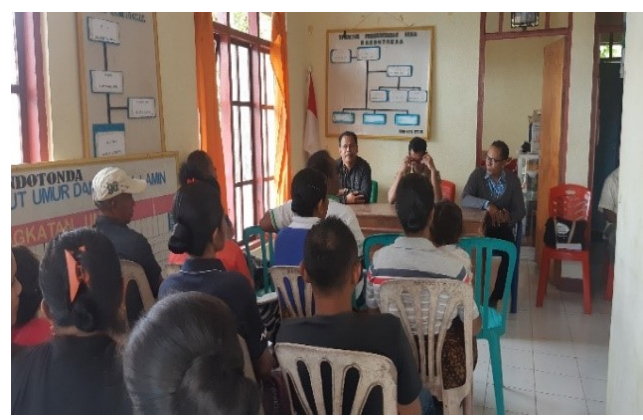

Gambar 1. Pendataan Area Lahan

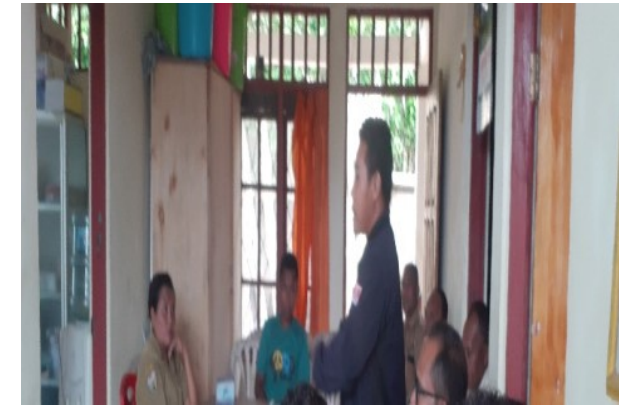

Gambar 2. Arahan dari tim pelaksana

Kegiatan penyuluhan bagi anggota kelompok tani dilaksanakan pada tanggal 3 Maret 2020, dihadiri pula camat Ende, kepala desa beserta staf, tokoh masyarakat dan tokoh adat. Materi yang diberikan meliputi: pengolahan tanah secara baik, teknik dan manfaat pembuatan guludan, pentingnya penentuan titik jarak tanam ubikayu dan kacang tanah, pemanfaatan sereza, teknik pengaplikasian promi, dan pentingnya pembumbunan serta pembersihan gulma. Anggota kelompok tani sangat antusias mengikuti kegiatan penyuluhan tersebut. Foto kegiatan penyuluhan pada Gambar 3 dan Gambar 4.

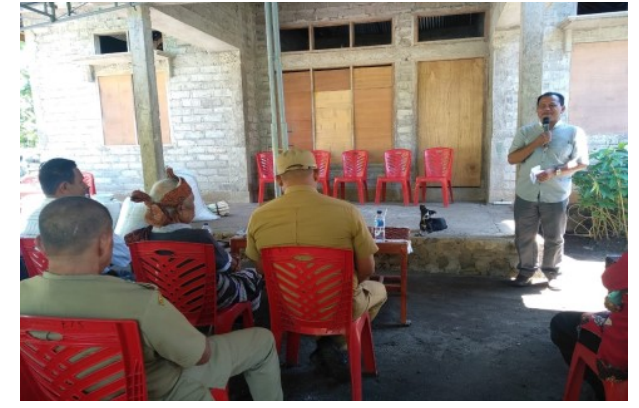

Gambar 3. Penyuluhan oleh ketua tim

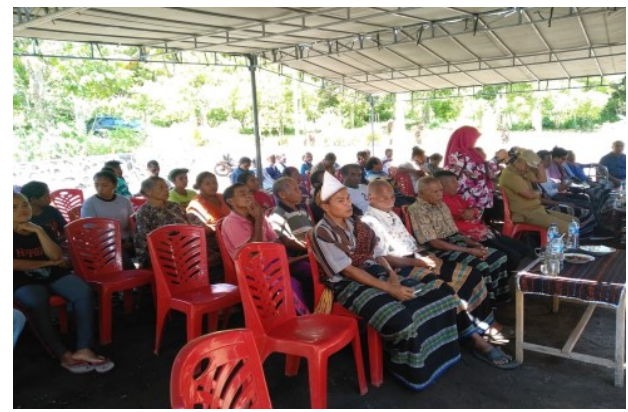

Gambar 4. Peserta penyuluhan

Tabel 1. Jadwal dan Materi Penyuluhan serta Pelatihan

\begin{tabular}{lcll}
\hline Hari/ Tanggal & Waktu & \multicolumn{1}{c}{ Materi } & Pemateri \\
\hline 3 Maret 2020 & $09.00-12.00$ & $\begin{array}{l}\text { Penyuluhan teknik } \\
\text { budidaya ubi kayu } \\
\text { Nuabosi }\end{array}$ & Universitas Flores \\
\hline 5 Maret 2020 & $09.00-12.00$ & $\begin{array}{l}\text { Pelatihan teknik } \\
\text { pembuatan guludan. }\end{array}$ & Universitas Flores \\
\hline 10 Maret 2020 & $09.00-12.00$ & $\begin{array}{l}\text { Pelatihan } \\
\text { pemanfaatan sereza } \\
\text { dan pemberian promi }\end{array}$ & Universitas Flores \\
\hline 15 Maret 2020 & $09.00-12.00$ & $\begin{array}{l}\text { Pelatihan pola tanam } \\
\text { tumpangsari }\end{array}$ & Universitas Flores \\
\hline 20 April 2020 & $09.00-12.00$ & Pelatihan & Universitas Flores \\
\hline
\end{tabular}

(C)To Maega / Jurnal Pengabdian Masyarakat. This is an open access article under the CC BY-SA 4.0 license (https://creativecommons.org/licenses/by-sa/4.0/). 


\section{pembersihan gulma}

dan pembumbunan

Kegiatan pelatihan dimulai pada tanggal 5 Maret 2020, diawali dengan pembersihan dan pengolahan lahan. Kegiatan tersebut dilakukan secara gotong royong, masyarakat terbiasa saling membantu diantara sesama, sehingga biaya tenaga kerja murah. Anggota kelompok tani mengolah lahan sambil bernyanyi dengan syair bahasa lokal, nyanyian tersebut mengandung makna, bekerja dengan sungguh-sungguh untuk kehidupan yang lebih baik. Aktivitas gotong royong dengan nyanyian ini dalam bahasa setempat disebut dengan hela jo. Foto kerja gotong royong pada Gambar 5.
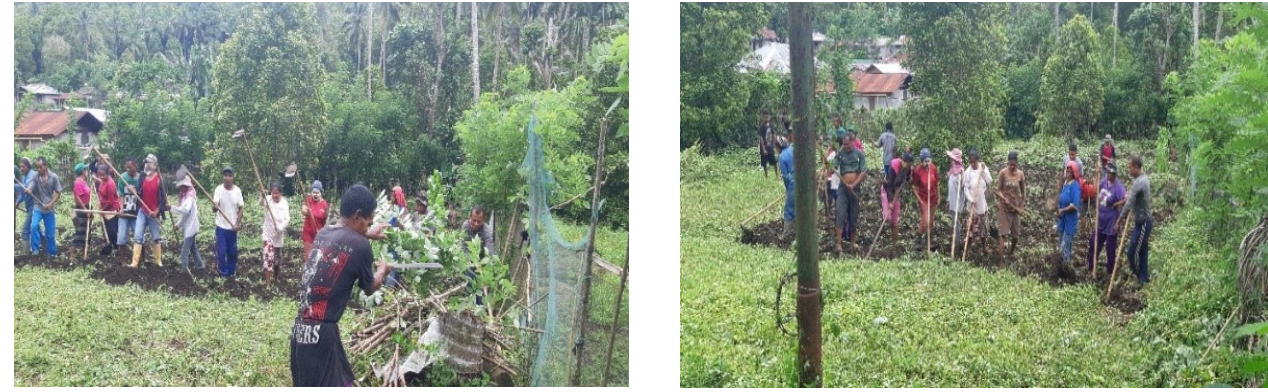

Gambar 5. Kegiatan pengolahan lahan

Pelatihan pembuatan guludan diawali dengan pengukuran jarak dari tepi lahan ke guludan sepanjang 1 meter, lebar guludan $50 \mathrm{~cm}$, jarak antar guludan 1,5 meter, kedalaman guludan $50 \mathrm{~cm}$. Manfaat pembuatan guludan adalah untuk memudahkan penyerapan air, memudahkan penyebaran akar tanaman dalam pembentukan umbi dan mengendalikan erosi. Hal ini sebagaimana dikemukakan oleh Jhonson dalam Henny et al., (2011), bahwa umumnya energi aliran permukaan akan menurun apabila terdapat hambatan seperti adanya tindakan konservasi tanah permukaan yang kasar atau sisa-sisa tanaman dipermukaan tanah. Oleh karena itu teknik pengolahan tanah dengan teknologi pembuatan guludan dapat menurunkan aliran permukaan dan sekaligus akan menurunkan jumlah tanah tererozi. Foto pelatihan pembuatan guludan oleh tim pakar pada Gambar 6 dan Gambar 7.

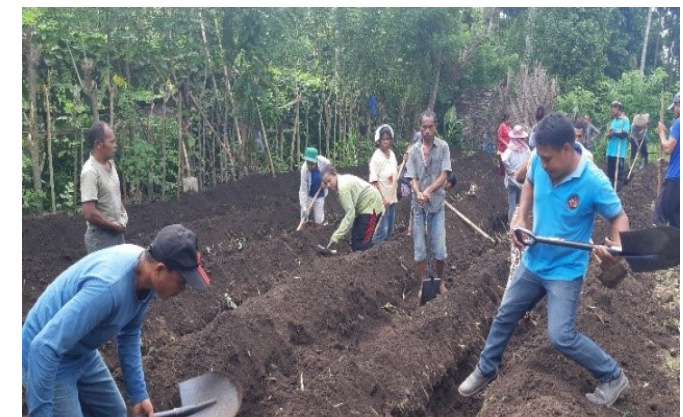

Gambar 6. Pelatihan Pembuatan Guludan

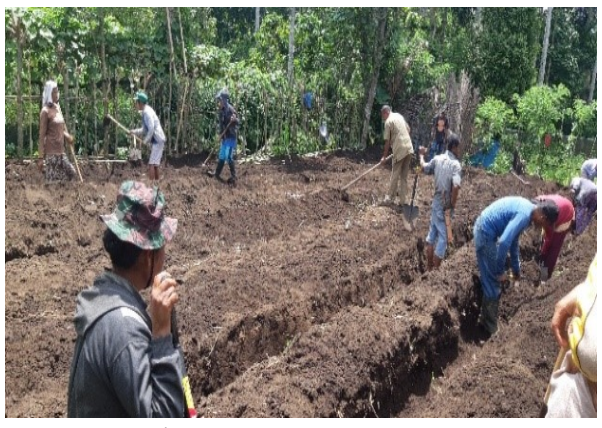

Gambar 7. Gotong royong 
Pelatihan hari kedua pada tanggal 10 Maret 2020 materi tentang pemanfaatan sereza dan pengaplikasian bahan aktif mikroba untuk mempermudah proses decomposer (promi). Sereza yang digunakan yaitu dari limbah tanaman (dedaunan dari tanaman cengkeh, kakao, hasil pembabatan dari pembersihan lahan dan serbuk kayu). Sereza dari hasil pembersihan lahan yang sifatnya agak keras dicacah terlebih dahulu untuk mempermudah proses dekomposisi, sedangkan dari dedaunan langsung diaplikasikan dalam guludan. Sebelum guludan ditutup dengan tanah dilakukan pelatihan aplikasi bahan aktif mikroba untuk mempermudah proses dekomposer, dengan perbandingan 1 gram/ liter air. Bahan aktif mikroba yang sudah dicampur air sesuai dengan perbandingan, disemprot menggunakan hand sprayer pada sereza limbah tanaman yang ada di dalam guludan. Promi memiliki kandungan mikroba yang sangat bermanfaat bagi pertumbuhan tanaman dengan penyemprotan promi membantu pempercepat proses dekomposes. Hasil analisis pupuk kandang menggunakan bioaktivator promi dalam penelitian Trivana \& Pradhana, (2017) menunjukkan biokativator promi yang memenuhi parameter-parameter SNI 19 -7030- 2004 adalah dengan waktu pengomposan selama 20 hari. Hal ini sebagaimana dikemukakan oleh Isroi. \& Purwantara., (2009), bahwa promi adalah formula mikroba unggul yang mengandung mikroba pemacu pertumbuhan tanaman, pelarut hara terikat tanah, pengendali penyakit tanaman, dan dapat menguraikan limbah organik pertanian/perkebunan. Bahan aktif promi adalah mikroba unggul yaitu Trichoderma harzianum DT 38, T. pseudokoningii DT 39, Aspergillus sp, dan mikroba pelapuk. Foto pembenaman sereza dan pencampuran promi bersama air di hand sprayer pada Gambar 8 dan gambar 9.

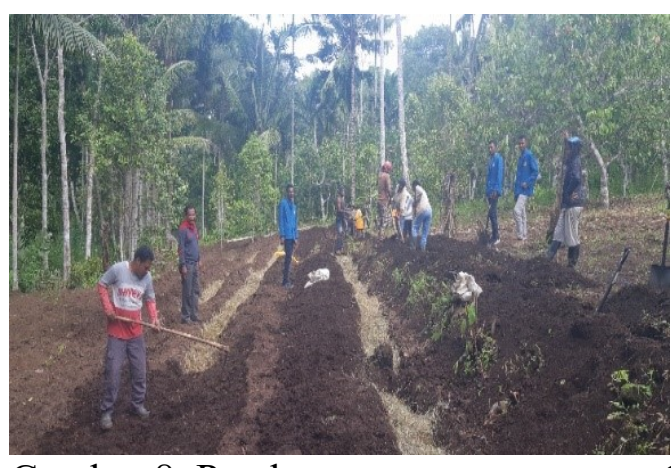

Gambar 8. Pembenaman sereza

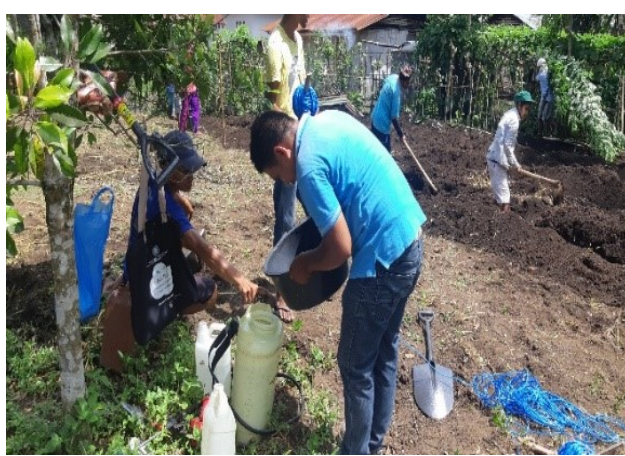

Gambar 9. Pencampuran promi dengan air

Pelatihan hari ketiga pada tanggal 15 Maret 2020, materi tentang pola tanam tumpangsari. Batang ubikayu yang digunakan pada pelatihan ini berasal dari varietas lokal ubikayu Nuabosi, dengan ukuran stek panjang $20-25 \mathrm{~cm}$, sedangkan kacang tanah dari varietas jerapah. Batang ubikayu setelah dipotong 20 - $25 \mathrm{~cm}$ dibiarkan selama satu hari, setelah itu potongan stek ubi kayu ditanam bagian pangkal dengan posisi tegak di gundukan guludan dengan kedalamam \pm 5 $\mathrm{cm}$ dengan jarak tanam dalam baris $1 \mathrm{~m}$ dan jarak tanam antar baris menyesuaikan (C)To Maega / Jurnal Pengabdian Masyarakat. This is an open access article under the CC BY-SA 4.0 license (https://creativecommons.org/licenses/by-sa/4.0/). 
jarak guludan yaitu 1 - 1,5 m. Kacang tanah dipisahkan dari kulit atau dikupas kulit buah, lalu biji kacang tanah diseleksi yaitu dipilih yang bernas dan tidak terserang hama dan penyakit, kemudian direndam dengan air yang sudah dicampur sevin (bahan kimia untuk mengendalikan semut). Penanaman kacang tanah dapat dilakukan bersamaan dengan penanaman ubi kayu atau 1 minggu setelah penanaman ubi kayu. Kacang tanah di tanam menggunakan jarak tanam 30 x $30 \mathrm{~cm}$ sedangkan jarak tanam kacang tanah dengan ubi kayu 1 x jarak tanam kacang tanah yaitu $30 \mathrm{~cm}$ atau rata-rata 2-3 baris kacang tanah yang dapat ditanami diantara baris tanaman ubi kayu. Foto pelatihan pola tanam tumpangsari pada Gambar 10.
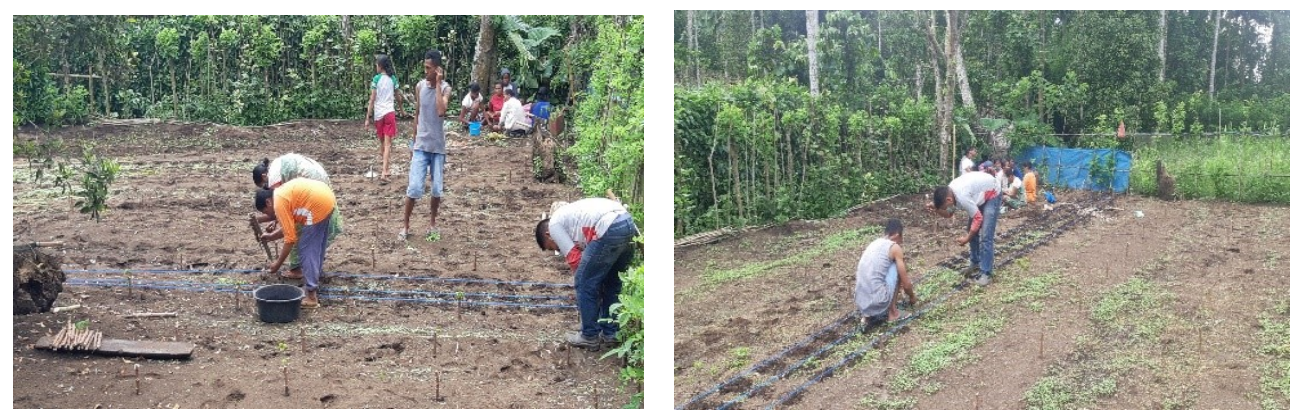

Gambar 10. Pelatihan pengaturan jarak tanam ubikayu dan kacang tanah

Pengaturan jarak tanam dalam sistem tanam tumpangsari memiliki peranan yang sangat penting untuk meminimalisir persaingan dalam memperoleh faktor tumbuh baik unsur hara, air, cahaya matahari maupun ruang tumbuh. Persaingan akan terjadi apabila individu dari suatu kelompok tanaman hadir dalam suatu kelompok tanaman yang lain, sementara faktor tumbuh berada pada kondisi yang terbatas.

Pelatihan hari keempat dilaksanakan pada tanggal 20 April 2020, materi yang diberikan tentang teknik pembumbunan dan pembersihan gulma. Pembumbunan dilakukan untuk memperkokoh batang tanaman, menciptakan kondisi tanah yang gembur, dan memberikan lingkungan perakaran yang lebih baik bagi tanaman, pembumbunan juga bertujuan menutup kembali akar dari tanaman yang bermunculan di atas permukaan tanah, mempermudah penyerapan zat-zat hara yang ada di dalam tanah dan untuk memperbaiki aerasi (peredaran udara) sedangkan pembersihan gulma memiliki peranan yang sangat penting agar sedapat mungkin meminimalisir terjadinya persaingan faktor tumbuh yang akan memberikan dampak yang negatif terhadap pertumbuhan tanaman. Foto pembersihan gulma dan pembumbunan pada Gambar 11 . 

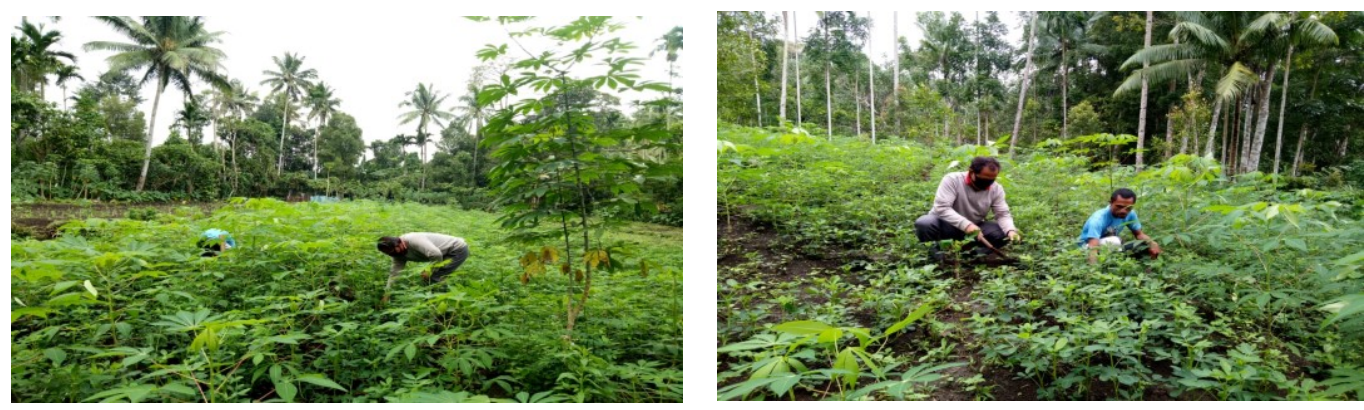

Gambar 11. Pelatihan pembumbunan dan pembersihan gulma.

Perubahan pengetahuan peserta sebelum dan setelah mengikuti pelatihan untuk keempat materi di atas diukur melalui pretest dan posttest, soal yang diberikan dalam bentuk pilihan ganda sebanyak 15 soal. Data pada Tabel 2, memberi gambaran jumlah soal benar baik untuk pretest maupun posttest, dari keempat kelompok materi yang diberikan. Berdasarkan data yang ada pada Tabel 2, diketahui bahwa terjadi peningkatan pengetahuan petani yang signifikan, hal ini terlihat dari jawaban benar untuk materi teknik pembuatan guludan, rata-rata pretest 5,68, posttest meningkat sebesar 12,6, materi pemanfaatan sereza dan pemberian promi rata-rata pretest 5,52 , posttest meningkat sebesar 13,64 , materi pola tanam tumpangsari rata-rata pretest 5,6, posttest meningkat sebesar 13,56 dan untuk materi pembumbunan dan pembersihan gulma, rata-rata pretest 5,52, posttest meningkat sebesar 14,2. Peningkatan pengetahuan ini disebabkan karena efektivitas dari metode pelatihan yang digunakan, dimana pelatihan yang diberikan dalam bentuk demonstrasi langsung di kebun petani.

Tabel 2. Hasil Pretest dan Posttest Materi Pelatihan Pembuatan Guludan, Pemanfaatan Sereza dan Pemberian Promi, Pelatihan Pola Tanam Tumpangsari, dan Pelatihan Pembumbunan serta Pembersihan Gulma

\begin{tabular}{|c|c|c|c|c|c|c|c|c|c|}
\hline \multirow[b]{2}{*}{ No } & \multirow[b]{2}{*}{ Nama } & \multicolumn{2}{|c|}{ Materi I } & \multicolumn{2}{|c|}{ Materi II } & \multicolumn{2}{|c|}{ Materi III } & \multicolumn{2}{|c|}{ Materi IV } \\
\hline & & Pretest & $\begin{array}{l}\text { Postte } \\
\text { st }\end{array}$ & Pretest & Posttest & Pretest & Posttest & Pretest & $\begin{array}{l}\text { Postte } \\
\text { st }\end{array}$ \\
\hline 1 & Stefania S. Sera & 5 & 15 & 6 & 13 & 6 & 14 & 6 & 15 \\
\hline 2 & Fernandes Soro & 4 & 9 & 5 & 13 & 4 & 12 & 5 & 14 \\
\hline 3 & Olivia B.S. Siti & 6 & 14 & 6 & 14 & 7 & 13 & 5 & 14 \\
\hline 4 & Marianus Bou & 5 & 10 & 6 & 13 & 7 & 14 & 5 & 14 \\
\hline 5 & Blasius Sa & 5 & 13 & 4 & 13 & 5 & 14 & 4 & 15 \\
\hline 6 & Lorensius Setu & 5 & 10 & 7 & 15 & 6 & 13 & 6 & 15 \\
\hline 7 & Marselinus M. & 7 & 12 & 6 & 14 & 6 & 11 & 5 & 14 \\
\hline 8 & Stefanus Paru & 6 & 12 & 7 & 15 & 6 & 15 & 5 & 15 \\
\hline 9 & $\begin{array}{l}\text { Delvina } \\
\text { Marselina }\end{array}$ & 5 & 13 & 4 & 13 & 5 & 13 & 4 & 13 \\
\hline 10 & Anastasia Bhara & 5 & 10 & 6 & 14 & 7 & 15 & 6 & 14 \\
\hline 11 & Yuliana Pano & 6 & 13 & 5 & 13 & 6 & 14 & 5 & 15 \\
\hline 12 & Epifania Dhawe & 6 & 12 & 4 & 14 & 5 & 14 & 6 & 14 \\
\hline 13 & Anastasia Iva & 6 & 13 & 5 & 12 & 5 & 13 & 5 & 15 \\
\hline 14 & Maria Th. Kale & 5 & 12 & 4 & 14 & 6 & 14 & 7 & 15 \\
\hline 15 & Crensesia A. Ita & 6 & 14 & 6 & 13 & 6 & 14 & 6 & 14 \\
\hline
\end{tabular}

(C)To Maega / Jurnal Pengabdian Masyarakat. This is an open access article under the CC BY-SA 4.0 license (https://creativecommons.org/licenses/by-sa/4.0/). 
[ 101 ] Willybrordus L., dkk / To Maega : Jurnal Pengabdian Masyarakat, Vol.3; No.2; Agustus, 2020

\begin{tabular}{|l|l|c|c|c|c|c|c|c|c|}
\hline 16 & Rikardus Era & 7 & 15 & 6 & 14 & 5 & 15 & 7 & 14 \\
\hline 17 & Iganasius Setu & 6 & 13 & 5 & 13 & 4 & 14 & 4 & 13 \\
\hline 18 & Saferinus Pati & 7 & 14 & 7 & 15 & 6 & 14 & 6 & 14 \\
\hline 19 & Bernadus Resi & 4 & 12 & 5 & 14 & 5 & 13 & 5 & 14 \\
\hline 20 & Kanisius Fidelis & 7 & 14 & 6 & 14 & 4 & 13 & 6 & 15 \\
\hline 21 & Kamilus Iko & 5 & 13 & 5 & 13 & 6 & 14 & 5 & 14 \\
\hline 22 & Falentinus Penga & 6 & 13 & 6 & 14 & 7 & 13 & 7 & 13 \\
\hline 23 & Alexander Weka & 5 & 12 & 6 & 14 & 5 & 13 & 6 & 14 \\
\hline 24 & Yuventus Sega & 7 & 13 & 6 & 13 & 6 & 14 & 7 & 14 \\
\hline 25 & Maria G. Yeti & 6 & 14 & 5 & 14 & 5 & 13 & 5 & 14 \\
\hline & Rata-Rata & 5,68 & 12,6 & 5,52 & 13,64 & 5,6 & 13,56 & 5,52 & 14,2 \\
\hline
\end{tabular}

Keterangan:

Materi I = Pelatihan teknik pembuatan guludan.

Materi II $\quad=$ Pelatihan pemanfaatan sereza dan pemberian promi

Materi III = Pelatihan pola tanam tumpangsari

Materi IV = Pelatihan pembumbunan dan pembersihan gulma

\section{Kesimpulan}

Pelaksanaan pelatihan teknik budidaya ubikayu Nuabosi dengan menggunakan teknologi pola tanam tumpangsari dengan tanaman legun di Desa Randotonda dapat berjalan dengan baik dan lancar serta mencapai hasil yang diharapkan. Hal ini terlihat dari pretest dan posttest yang diberikan, dimana terjadi peningkat nilai yang signifikan pada posttest. Pada materi teknik pembuatan guludan rata-rata pretest 5,68, posttest meningkat sebesar 12,6, materi pemanfaatan sereza dan pemberian promi, rata-rata pretest 5,52, posttest meningkat sebesar 13,64, materi pola tanam tumpangsari rata-rata pretest 5,6, posttest meningkat sebesar 13,56 dan untuk materi pembumbunan dan pembersihan gulma, rata-rata pretest 5,52, posttest meningkat sebesar 14,2.

\section{Ucapan Terimakasih}

Penulis menyampaikan ucapan terimakasih kepada, (1) Kemenristek/Brin Jakarta melalui DRPM, sehubungan dengan bantuan dana Kegiatan Pengabdian Kepada Masyarakat Skema Program Pengembangan Desa Mitra (PPDM) di Desa Randotonda Kecamatan Ende Kabupaten Ende Propinsi NTT Tahun Anggaran 2020. (2) Rektor dan LPPM Universitas Flores yang telah membantu tim pengabdian kepada masyarakat sehubungan dengan kelancaran urusan administrasi dan kemudahan dalam menggunakan fasilitas kampus. (3) Kepala Desa Randotonda dan ketua serta anggota kelompok tani Kema Tau Pawe, yang telah bersama-sama melakukan kegiatan pengabdian kepada masyarakat di tahun 2020 .

\section{Daftar Pustaka}

Amanullah, M. M., Somasundaram, E., Vaiyapuri, K., \& Sathyamoorthi, K. (2007). Intercropping in Cassava - A Review. Agricultural Reviews, 28(3), CTo Maega / Jurnal Pengabdian Masyarakat. This is an open access article under the CC BY-SA 4.0 license (https://creativecommons.org/licenses/by-sa/4.0/). 
[ 102 ] Willybrordus L., dkk / To Maega : Jurnal Pengabdian Masyarakat, Vol.3; No.2; Agustus, 2020

$179-187$.

Arsa, I. G. B. ., Ndiwa, A. S. ., \& Seran, M. Y. (2015). Usulan Pelepasan Geragaan Ubikayu Varietas Nuabosi sebagai Calon Varietas Unggul. Fakultas Pertanian Universitas Nusa Cendana \& Dinas Pertanian dan Peternakan Kabupaten Ende.

BPS. (2018). Produktivitas Ubikayu di Indonesia. https://www.pertanian. go.id/Data5tahun/ TPATAP-2017(pdf)/ 37-ProdtvUbikayu.pdf

Chepng'etich, E. Nyamwaro S.O. Bett, E.K. and Kizito, K. (2015). Factors That Influence Technical Efficiency of Sorghum Production: A Case of Small Holder Sorghum Producers in Lower Eastern Kenya. Hindawi Publishing Corporation Advances in Agriculture, Volume 201, 1-11. https://doi.org/http:// dx.doi.org/10.1155/2015/861919

Francis, C., Jones, A., Crookston, K., Wittler, K., \& Goodman, S. (2006). Strip Cropping Corn And Grain Legumes: A Review. American Journal of Alternative Agriculture, 1 No. 4, 159-164. http://www.eap.mcgill.ca/MagRack/AJAA/AJAA_5.htm

Henny, H., Multilaksono, K., Sinukaban, N., \& Tarigan, S. D. (2011). Erosi Dan Kehilangan Hara Pada Pertanaman Kentang Dengan Beberapa Sistem Guludan Pada Andisol Di Hulu Das Merao, Kabupaten Kerinci Jambi. Jurnal Solum, 8(2), 43. https://doi.org/10.25077/ js.8.2.43-51.2011

Isroi., \& Purwantara. (2009). Pengomposan Limbah Pertanian dengan Promi. Pusat Penelitian Bioteknologi dan Bioindustri Indonesia. https://www.iribb.org/index.php/produk/jenis-produk/ decomposer/promi

Itam K.O., Ajah E.A., Ofem U.I \& Abam, O. E. (2015). Technical Efficiency Analysis of Small Scale Cassava Farmers in Cross River State, Nigeria: A Stochastic Production Frontier Approach. Applied Economics and Finance,. No. 4 ta, 10-19. https://www.google.com/search?safe

Li, H., Liu, L., Lin, C., \& Wang, S. (2011). Plant Uptake and In-Soil Degradation of PCB-5 Under Varying Cropping Conditions. Chemosphere, 84(7), 943949.https://doi.org/10.1016/j. chemosphere. 2011.06.007

Nyi, T. Mucheru-Muna, M. Shisanya, C. Paul Lodi Lama, J. Mutuo, P.K. Pypers, P.Vanlauwe, B. (2014). Effect of Delayed Cassava Planting on Yields and Economic Returns of a Cassava-Groundnut Intercrop in the Democratic Republic of Congo. World Journal of Agricultural Research, 2 No. 3, 101108. doi:10.12691/wjar-2-3-3

Sembirin, A. S. br, Ginting, J., \& Sitepu, F, E. (2015). Pengaruh Populasi Kacang Tanah (Arachis hypogaea L.) dan Jagung (Zea mays L.) terhadap Pertumbuhan dan Produksi Pada Sistem Pola Tumpang Sari. Jurnal Online Agroekoteknologi, 3 No. 1, 52-71. https://media.neliti. com/media/ 
publications/ 102508-ID-pengaruh-populasi-kacang-tanah-arachis-h.pdf

Shen, Q., \& Chu, G. (2004). Bi-Directional Nitrogen Transfer In An Intercropping System Of Peanut With Rice Cultivated In Aerobic Soil. Biology and Fertility of Soils, 40(2), 81-87. https://doi.org/10. 1007/s00374-004-0737-3

Sullivan, P. (2000). Intercropping Principles and Production PracticesAgronomy Systems Guide. Appropriate Technology Transfer for Rural Areas. Appropriate Technology Transfer for Rural Areas (ATTRA) P.O. Box 3657. https:/www. Iatp.org/sites/default/files/ Intercropping Principles_and_Production_Practi.htm

Trivana, L., \& Pradhana, A. (2017). Optimalisasi Waktu Pengomposan dan Kualitas Pupuk Kandang dari Kotoran Kambing dan Debu Sabut Kelapa dengan Bioaktivator PROMI dan Orgadec Time. Sain Veteriner, 35(1), 136144.

Zinsou, V., Wydra, K., Ahohuendo, B., \& Hau, B. (2004). Effect Of Soil Amendments, Intercropping And Planting Time In Combination on The Severity of Cassava Bacterial Blight and Yield in Two Ecozones of West Africa. Plant Pathology, 53(5), 585-595. https://doi.org/10.1046/j. 00320862.2004.01056. 